\title{
Site Selection of Sarein's Municipal Solid Waste Landfill Using the GIS Technique and SAW Method
}

\author{
Seiied Taghi Seiied Safavian, Ebrahim Fataei, Taghi Ebadi, and Ali Mohamadian
}

\begin{abstract}
With regard to increasing the population growth and increasing the volume and variety of urban wastes, sanitary landfill procedure is one of the most common excretion ways in different countries. There is several ways for locating the waste landfill sites. In this research it has been tried to select suitable site for waste landfill of tourist city of Sarein which is placed in north-western of Ardabil province in Iran country by using the GIS software package and integrating the Saw and AHP methods. For this purpose, in the first step Sarein's urban waste landfill site was selected based on Iran's Department of Environment's criteria with applying the GIS software and AHP method.

After overlaying of mentioned-criteria maps, four sites was selected that had maximum score by evaluating of properties of identified sites, one of sites was identified as the first priority by using the SAW method.
\end{abstract}

Index Terms-Sanitary landfill, multi-criteria analysis method, GIS software, Arbabil, Iran.

\section{THESE INTRODUCTION}

Waste is one of materials that has direct relationship with population increasing. This dirty gold has various problems at all of steps including production and landfill.

So that if it is not carefully planned, it will lead to economical and health problems. In these planning's, one of the complicated steps is locating of waste landfill sites waste landfill sites have precise steps including site selecting and preparation of waste landfill site. Each of these steps requires engineering studies and sound management [1] in selection of waste landfill sites in addition to the environmental considerations that must be addressed, including the distance from the river, distance from the fault, and distance from the Road and .... The waste landfill sites must be accepted by the people.

Because if these landfill sites is near the individual's workplace or living places, it is considered as a negative outcome and it may cause irreparable consequences to human life [2].

Manuscript received November 2, 2015; revised March 22, 2015.

Seiied Taghi Seiied Safavian is with the Young Researchers and Elite Club, Ardabil Branch, Islamic Azad University, Ardabil, Iran (e-mail: tagisafavian@gmail.com).

Ebrahim Fataei is with the Environmental Engineering Department, Ardabil Branch, Islamic Azad University, Ardebil, Iran (e-mail: ebfataei@gmail.com).

Taghi Ebadi is with the Faculty of Environmental Engineering, Amirkabir University of Technology, Tehran, Iran (e-mail: drtebadi@gmail.com).

Ali Mohamadian is with Technical College, University Dusseldorf, Düsseldorf, Germany (e-mail: a.mohammadian@iauardabil.ac.ir).
Currently, highly accurate tool was used for selecting and locating the waste landfill one of these tools is using the satellite data and GIS [2], [3]. Today, many researchers are using GIS capabilities for locating waste landfill site. Because geographic information system is able to analyze of vast volume of information layers [4], [5].

In this context, many studies can be mentioned that have been able to do waste landfill locating with good precision by using the GIS technique.

In 2003, wastara and Naswate have been conducted locating of American's urban landfill sites by using the GIS and RS with regard to criteria such as geology, fault, slope of the land and .... Also several researchers including Yeslinear, Cetrin, Al-Harrah, Qdais Kontos and et al have involved in locating waste landfill sites by using the GIS techniques [6]-[8]. Qdais, Kontos have used from multi-criteria analysis (MCDM) along with applying GIS Techniques for the best site selecting [8], [9].

In this research, locating and selecting of waste landfill site was implemented by using the GIS software and AHP method and also with applying the one of SAW decision methods. In the applied method problems formulating possibility as hierarchy has been provided and this possibility is provided in problems with regarding different qualitative and quantitative criteria [4]. In this method, work has been based on the even comparison that was simplified justification and calculations. Also it shows amount of consistency and consistency in multi-criteria decision [10], [11]. Therefore in this research, SAW method has been used for prioritizing of land fill site selection Tourist city of Sarein in geographical coordination of 48/040 eastern longitude and 38/090 northern latitude with up to $1280000 \mathrm{~m}^{2}$ area is placed in 28 Kilometers away from west of Ardabil city. And north-west of Iran. The city's average height is 1650 meters from sea level.

This city has 6121 settled population in 2011 in terms of last census. In addition to urban settled population, due to being tourist attractive, this city according to the cultural Heritage and Tourism organization of Ardabil province this city welcome 5200000 tourists from the country and all over the world. According to present statistics, maximum daily tourist number has bee report about 85000 people during the tourist presence peak in summer in rejoin.

The amount of waste production per capita in this city is 0.930 kilograms a day generally, in this city, something more than 6453 tones of waste is produced annually.

At present, neither recycling system nor separation from origin was conducted in this city.

Due to rapid development of tourist facilities and installations in this region, current landfill site would not respond to urban wastes landfill in future, there fore, locating 
a new site is necessary and this research has been conducted for considering this issue.

\section{MATERIALS AND METHODS}

In this study, for selecting suitable sites for locating and overlaying of layers was conducted by using GIS software and AHP method. In this step mapping was conducted based on department of environment's criteria (Table I). After overlaying of produced maps by $\mathrm{AH}$ that has been conducted with polling from expertise people about weighted ranking of mentioned criteria in expert choice software environment (plot 1). Suitable sites were specified for urban waste landfill in Sareing town's territory.

TABLE I: IRAN'S DEPARTMENT OF ENVIRONMENT CRITERIA FOR SELECTING LANDFILL

\begin{tabular}{|l|l|}
\hline The criteria & Mode of action and Conditions \\
\hline Fault & Minimum distance of 200 meters. \\
\hline $\begin{array}{l}\text { Surface water } \\
\text { resources }\end{array}$ & $\begin{array}{l}\text { Minimum horizontal distance of } 1000 \text { meters from } \\
\text { the river }\end{array}$ \\
\hline Groundwater & $\begin{array}{l}\text { Minimum depth of shallow groundwater and a } \\
\text { minimum horizontal distance of } 10 \text { meters to } 400 \\
\text { meters. }\end{array}$ \\
\hline Soil & $\begin{array}{l}\text { With topsoil as possible of silty clay and sandy silt in } \\
\text { the next phase of the }\end{array}$ \\
\hline Residential & $\begin{array}{l}\text { Minimum distance of } 1 \text { km from the rural areas and } \\
\text { Limits the minimum distance of } 1 \text { km }\end{array}$ \\
\hline Geology & $\begin{array}{l}\text { A possible bedrock of igneous rocks and is } \\
\text { impermeable. }\end{array}$ \\
\hline Roads & Minimum distance of 300 meters. \\
\hline Slope & Slope of less than $20 \%$ \\
\hline Land & $\begin{array}{l}\text { Have valuable uses such as agriculture, forest, } \\
\text { wetland and grassland there. }\end{array}$ \\
\hline Airport & Privacy International Airport $3 \mathrm{~km}$ from eight local \\
\hline
\end{tabular}

Priorities withrespect to:

Goal: site selection

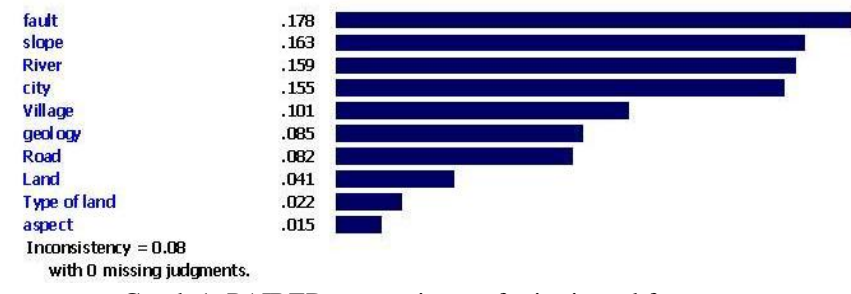

Graph 1: PAIRED comparisons of criteria and factors.
In continue, for selecting of the best choice by using the SAW model, each criterion's interior matrices were completed by extracting interior information from each landfill cite and questionnaire setting.

In multi-criteria decision, problems and specifically multi-induces decision problems, having and knowing the relative weight of present indices had been effective step in problem solving process. From determining methods of weights of indices, following methods can be mentioned:

1) Applying the elite's response

2) Linmp method

3) Least squares method

4) Special vector technique

5) Shanon's entropy and so on.

In this research, Shanon entropy method has been used as one of the most popular methods of calculating the indices weights for achieving indices relative weights entropy in social sciences, physics and information theory when a design matrix's data is completely specified Shanon's entropy method could be used for evaluating the weights.

The idea behind this method is that the more the dispersion in values of an index the more important that index than the other indices.

Scoring steps to indices by using the Shanon's Entropy includes:

1) Data matrix formation: Table II is showing 10 parameters related to department of environment's criteria that have been used as index in SAW method for place evaluating of data. In SAW method, for data matrix formation, each data's matrix cell has been completed by expert's comments and GIS and AHP software's output (Table III).

TABLE II: PARAMETER OF THE 10'S

\begin{tabular}{|c|l|}
\hline Index & Descriptions \\
\hline $\mathrm{C}^{-}{ }_{1}$ & Slope \\
\hline $\mathrm{C}^{+}{ }_{2}$ & Aspect \\
\hline $\mathrm{C}^{+}{ }_{3}$ & Land \\
\hline $\mathrm{C}^{+}{ }_{4}$ & Tip of land \\
\hline $\mathrm{C}^{+}{ }_{5}$ & Geology \\
\hline $\mathrm{C}^{+}{ }_{6}$ & Fault \\
\hline $\mathrm{C}^{+}{ }_{7}$ & River \\
\hline $\mathrm{C}^{+}{ }_{8}$ & Road \\
\hline $\mathrm{C}^{+}{ }_{9}$ & City \\
\hline $\mathrm{C}^{+}{ }_{10}$ & Rural \\
\hline &
\end{tabular}

TABLE III: PARAMETER OF THE 10'S

\begin{tabular}{|c|c|c|c|c|c|c|c|c|c|c|}
\hline Indicators Options & $\mathrm{C}^{-}{ }_{1}$ & $\mathrm{C}^{+}{ }_{2}$ & $\mathrm{C}^{+}{ }_{3}$ & $\mathrm{C}^{+}{ }_{4}$ & $\mathrm{C}^{+}{ }_{5}$ & $\mathrm{C}^{+}{ }_{6}$ & $\mathrm{C}^{+}{ }_{7}$ & $\mathrm{C}^{+}{ }_{8}$ & $\mathrm{C}^{+}{ }_{9}$ & $\mathrm{C}^{+}{ }_{10}$ \\
\hline $\mathrm{A}_{1}$ & 8 & 5 & 5 & 7 & 9 & 6 & 9 & 10 & 5 & 5 \\
\hline $\mathrm{A}_{2}$ & 4 & 6 & 3 & 5 & 3 & 3 & 9 & 8 & 5 & 3 \\
\hline $\mathrm{A}_{3}$ & 2 & 4 & 4 & 2 & 4 & 2 & 4 & 6 & 3 & 4 \\
\hline $\mathrm{A}_{4}$ & 1 & 6 & 4 & 2 & 1 & 1 & 3 & 6 & 2 & 4 \\
\hline
\end{tabular}

2) Descaling of decision matrix by using the clock method: After provision of first matrices, because different indices may had different scales, used indices must be released from scale and indices without consistency must be remover. Descaling is obtained in terms of equation 1 :

$$
P_{i j}=\frac{r_{i j}}{\sum_{i=1}^{m} r_{i j}}
$$

$P_{i j}=$ descaled number of indices $r_{i j}=$ scores of indices

3) Index entropy calculation. In the third step, we find indices entropy by using the equation 2 .

$$
E_{j}=-K \sum_{i=1}^{m}\left[P_{i j} \ln P_{i j}\right]
$$

$K$ amount obtained by equation 3 .

$$
K=\frac{1}{\operatorname{Ln}(m)}
$$


$m=$ number of choices.

4) Calculating the lack of confidence or degree of deviation: In the fourth step, we calculated deviation degree amount for any amount by equation 4 .

$$
d_{j}=1-E_{j}
$$

$d_{j}=$ degree of deviation.

5) Calculating the indices weight: in the final step, we obtained indices weight by using the equation 5 that these weights has been presented in Table III.

$$
W_{j}=\frac{d_{j}}{\sum_{j=1}^{n} d_{j}}
$$

$W_{j}=$ indices weight.

After obtaining the indices weight by using the Shanon entropy, in the line of research, SAW method has been applied for ranking landfill sits.

1) Data matrix formation: this research's data matrix was presents in Table III.

2) Linear de-scaling of decision matrix amounts there formula has been used for descaling in this model. If we have positive aspect in matrix, then we apply equation 6 .

$$
n_{i j}=\frac{a_{i j}}{\operatorname{Max} a_{i j}}
$$

$a_{i j}=$ indices score.

If we have negative aspect in matrix, we apply equation 7 .

$$
n_{i j}=1-\frac{a_{i j}}{\operatorname{Max} a_{i j}}
$$

If we have both negative and positive aspects we apply equation 8 .

$$
n_{i j}=\frac{\frac{1}{a_{i j}}}{\frac{1}{\operatorname{Max} a_{i j}}}
$$

3) Multiplying de-scaled matrix by weights of indices.

In this step, we multiplied weight of indices obtained from Shanon entropy by de scaled matrix and, then add together and in this way each landfill site's weight was obtained. This step could be written as equation 9 .

$$
W_{\text {total }}=W_{s h} \times N
$$

\section{DISCUSSION AND CONCLUSION}

In this study, suitable sites were determined for Sarein town's sanitary landfill by using the GIS capability and weighting product of AHP method (Fig. 1).

After specifying four sites in Sarein town's territory for sanitary urban waste landfill site through SAW method and also Shanon entropy method for scoring of indices related to department of environment, prioritizing of most suitable landfill sites was conducted.

Results of Shanon entropy have been shown in Table IV and also final scores of selected landfill sites shown in Table $\mathrm{V}$. In accordance with calculated scores in Table V, the best selected site was place 1. Fig. 2 is showing position of

\begin{tabular}{|c|c|c|c|c|c|c|c|c|c|c|}
\hline Indicators & $\mathrm{C}_{1}^{-}$ & $\mathrm{C}_{2}^{+}$ & $\mathrm{C}^{+}{ }_{3}$ & $\mathrm{C}^{+}{ }_{4}$ & $\mathrm{C}^{+}{ }_{5}$ & $\mathrm{C}_{6}^{+}$ & $\mathrm{C}^{+}{ }_{7}$ & $\mathrm{C}_{8}^{+}$ & $\mathrm{C}_{9}^{+}$ & $\mathrm{C}^{+}{ }_{10}$ \\
\hline Weight & 0.218 & 0.070 & 0.012 & 0.123 & 0.237 & 0.164 & 0.088 & 0.019 & 0.053 & 0.012 \\
\hline
\end{tabular}
selected region in Iran country and Ardabil province and Sarein town (Fig. 2).

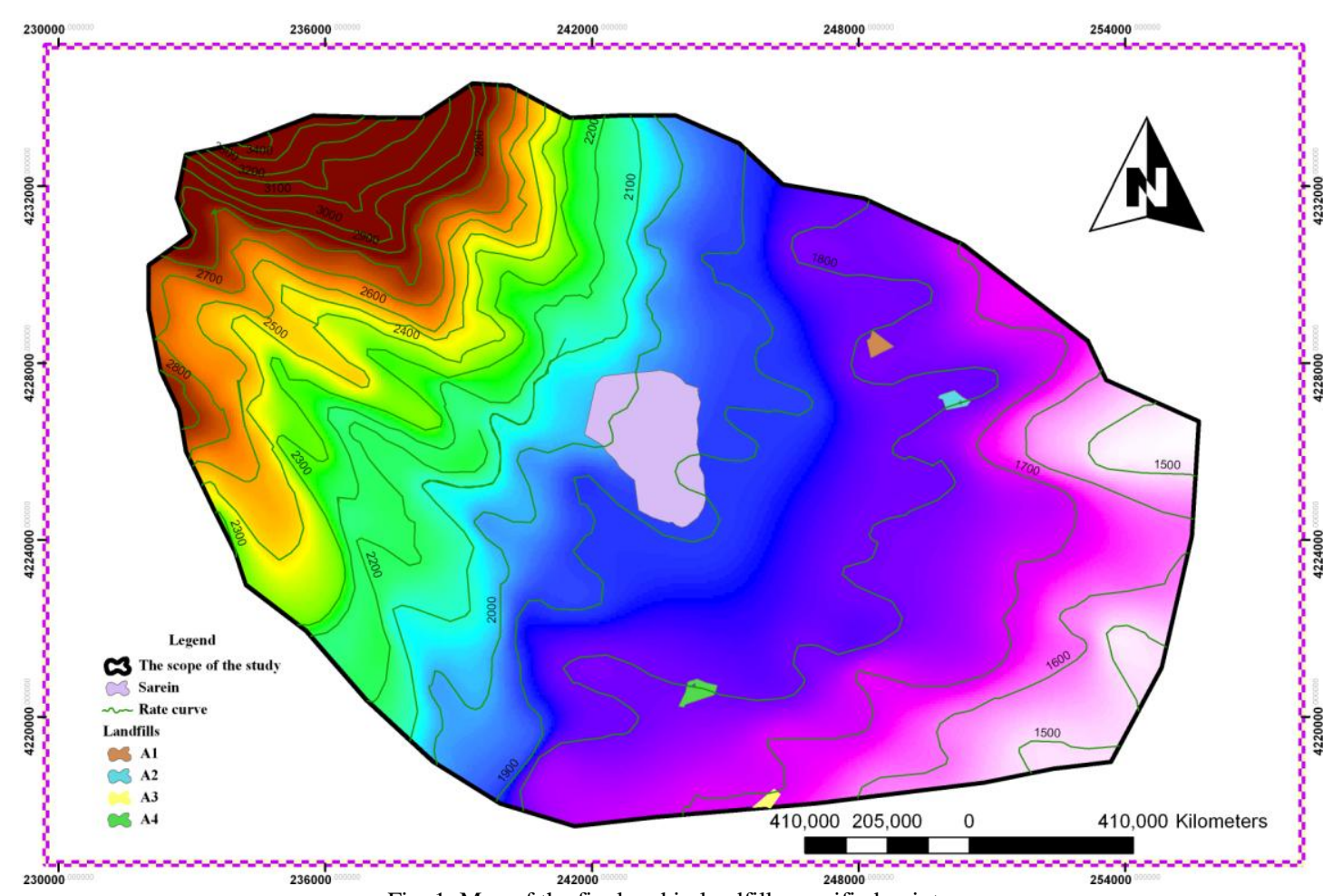

Fig. 1. Map of the final and in landfills specified points.

TABLE IV: SCORES WERE CALCULATED USING THE SHANNON ENTROPY INDEX 


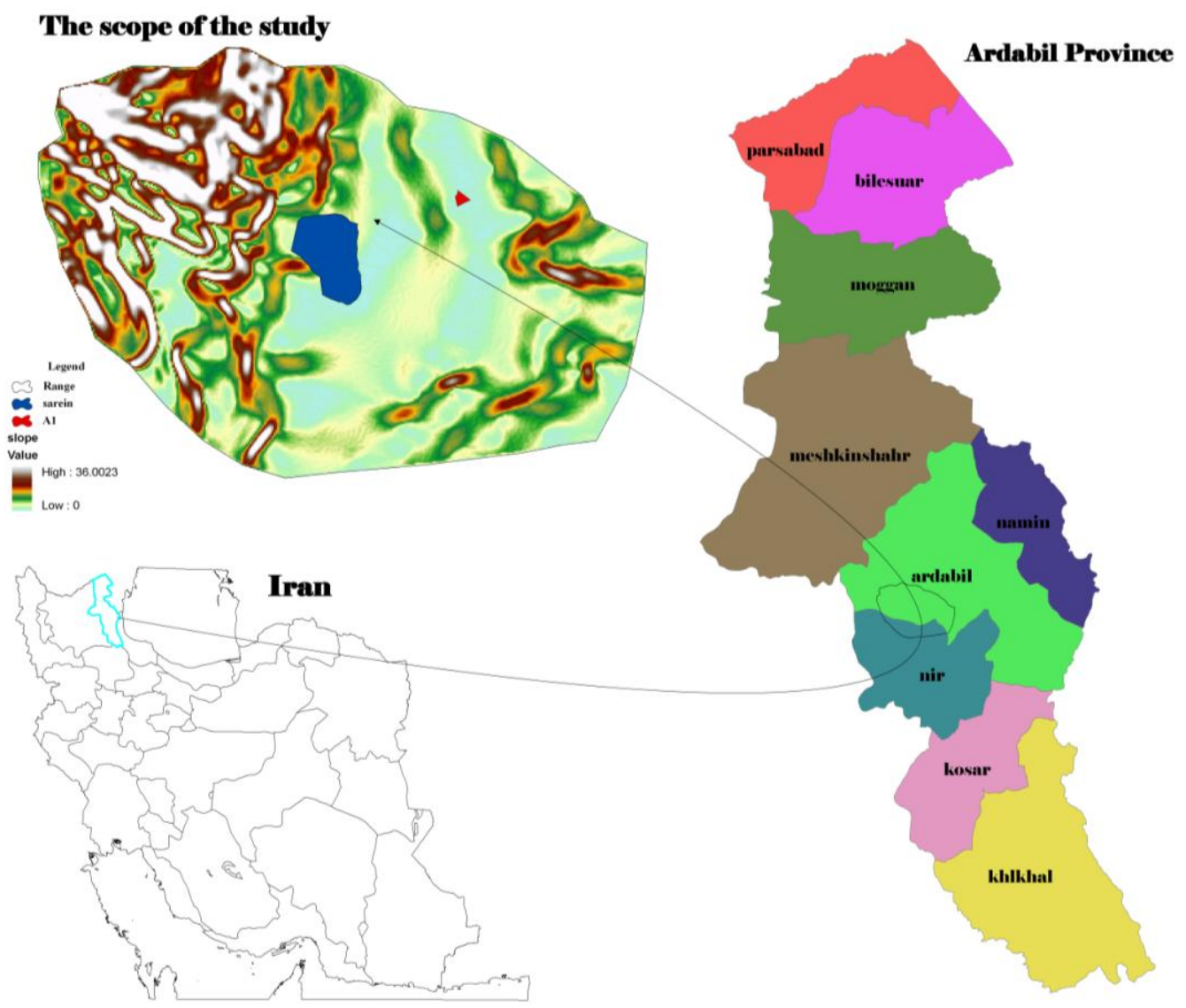

Fig. 2. Location of selected sites and Ardabil in Iran.

TABLE V: SCORES WeRE CALCULATED USING THE SAW METHOD FOR

\begin{tabular}{|c|c|c|c|c|}
\hline Landfills & $\mathrm{A}_{1}$ & $\mathrm{~A}_{1}$ & $\mathrm{~A}_{1}$ & $\mathrm{~A}_{1}$ \\
\hline Score & 0.985 & 0.596 & 0.503 & 0.428 \\
\hline
\end{tabular}

\section{CONCLUSION}

In this study, GIS software's capability and weighting through AHP method in expert choice software's environment was used for the locating of Sarein town's sanitary waste landfill site. SAW method has been used for determining the best site from specified sites. Results showed that the best site is the choice of A1 place that is placed in 400 meters distance from road which has 2 percent general slope. Results obtained from field studies implies that selected region has maximum distance from surface and underground waters and its geology structure generally is impervious metamorphic rocks and the selected region is kind ofarid lands and low steppe's plant covering. The field evaluations of present study in light of specified landfill sites and first determined place priority through SAW method showed that combinatorial application of GIS software and AHP and the SAW method could allow researchers to locate sites with high accuracy.

\section{REFERENCE}

[1] H. Neyma, "Locating solid waste materials landfill site by using the GIS for Tehran City," Master's Thesis, Technical Faculty, University of Tarbiyat Modarras, 2000.
[2] M. Masoud, Locating Solid Waste Materials Landfills Sites, Bearie of Human Environment, Department of Environment, Tehran, 1999, pp. 45-99.

[3] J. R. Eastman, IDRISI for Windows Users Guide, Clark Labs for Cartographic Technology and Geographic Analysis, Clarc University, 1997.

[4] G. F. Bonham, Carter, GIS for Geoscientists, Modeling with GIS and Disposal, The General Services Administration's, USA.

[5] A. Guzman and J. Reyes, "Solid waste management: Mapping out solutions at the local level," Local Government Support Program, Services with Impact: Resources books for Local Government, Manila, Philippines, pp. 102-125, 2003.

[6] A. J. Omar and A. Q. Hani, "Municipal solid waste landfill siting, using intelligent system," Waste Management, vol. 3, pp. 299-306, 2005.

[7] M. S. Kuo and G. S. Liang, "Combining VIKOR with GRA techniques to evaluate service quality of airports under fuzzy environment," Expert Systems with Applications, pp. 1304-1312, 2011.

[8] C. Jones, "Investment analysis and management," International Journals of Jhon Willey \& Sons, pp. 192-195, 1998.

[9] F. Sortino and N. P. Lee, "Performance measurement in a downside risk framework," Investing, pp. 59-64, 1994.

[10] S. Liu and Y. Lin, Grey Information Theory and Practical Applications, London, Springer, 2006, pp. 55-68.

[11] K. David, Grey System and Grey Relational Model, ACM SIGICE Bulletin, 2007, pp. 1-9.

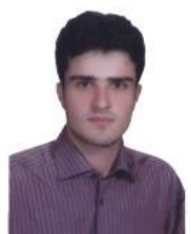

Seiied Taghi Seiied Safavian is a graduate student at Amirkabir University of Technology in the field of environmental engineering resident.

$\mathrm{He}$ is the owner of 7 articles ISI, over 45 conference papers, more than 8 patents, 1 book (in print), the academic peer 3 research projects, 20 project partners outside the university.

He has got the President's Award for Research. He is a student researcher at University of Technology. 